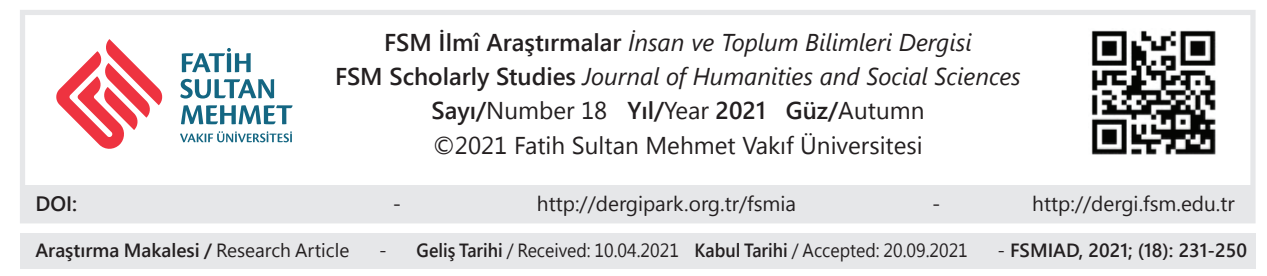

\title{
Hava Kirliliği, Bileşenleri ve Sağlık Fevzi Yılmaz*
}

\section{$\ddot{O} z$}

Büyük şehirlerde ve endüstri bölgelerinde hava kirliliği ile mücadele ana görevdir. Çevreyi ve canlı yaşamı koruma kısaca ölümleri önleme, ulaşım gibi muhtelif kaynaklardan gelen toz ve gaz çıkışlarını kesme veya azaltmadan geçer. Kirli hava ve havadaki tozla uzun süreli temas insan sağlığını özellikle sinir ve dolaşım sistemini olumsuz etkiler. Diğer taraftan, çöl tozlarının meteorolojisi ve toz kimyasının canlı yaşama katkıları herkesi şaşırtmaktadır. Gerçekler ve bulgular, ülkelerin KOVID-19 Salgını nedeniyle içine düştükleri ekonomik daralma sonucu olarak hava kirliliğinden daha az etkilendiklerini göstermiştir.

Anahtar Kelimeler: Şehir tozları, çöl tozları, araç emisyonları, kirlilik, sağlık.

\footnotetext{
* Prof. Dr., Fatih Sultan Mehmet Vakıf Üniversitesi Mühendislik Fakültesi İnşaat Mühendisliği
} Bölümü, İstanbul/Türkiye, f.yilmaz@fsm.edu.tr, orcid.org/0000-0003-3381-3035. 


\title{
Air Pollution, Components and Health
}

\begin{abstract}
To combat air pollution in big cities and industrial areas is main issue. Protecting environment and save the lives, shortly prevent deaths depends on cutting or reducing dust emissions from various sources such as trasportation. Prolonged exposure of dirty weather and dusts affects human healths, especially nervous and circulatory systems. On the other hand, meteorology of desert dusts and supporting affect of dusts chemistry to life are astonishing everybody. Facts and findings have indicated that economical slowdown of countries during COVID-19 Pandemic lead to little air pollution effect.
\end{abstract}

Keywords: City dusts, dusts from desert, car emissions, pollution, health. 


\section{Giriş}

Canlı-cansız varlıkların uyumlu birlikteliği ve temiz çevrenin ne kadar önemli olduğunu son yaşadığımız KOVID-19 küresel salgınında bir kere daha anladık. Doğal (çöl tozları gibi) ve yapay (endüstri tozları gibi) toz ve gaz çıkışları ve taşınımları insan sağlığı açısından çok önemlidir. Bunların, doğal yaşama etkileri yanında, astronomik olaylarla da ilişkileri vardır.

Malzeme ve enerjiyi kullanarak biz insanlar uygarlıklarımızı inşa ettik ve süreç boyunca başta toz ve dumanlar olmak üzere çevreye kirleticileri saldık. Yanardağ püskürmeleri, yangınlar ve çöl tozları gibi doğa hadiseleri de hava kirliliği oluşturmaktadır. İnsanoğlu tükettiği enerjinin \%80’inini kirletici fosil yakıtlardan (petrol, kömür ve doğal gaz gibi) sağlamaktadır. \%20'lik kısım ise, başta hidroenerji ve nükleer olmak üzere diğer kaynaklardan (güneş, rüzgâr ve biyoenerji gibi) gelmektedir. ${ }^{1}$ Kullandı̆̆ımız enerjinin ikincil formu olan elektrik enerjisi, kömürlü termik santrallar ve doğalgaz çevrim santralları yanında büyük ölçüde yenilenebilir enerji kaynaklarından (hidroelektrik, rüzgar, PV Güneş ve biyoenerji gibi) ve nükleerden elde edilir. Dünya toplam enerji tüketimindeki payı \%4-7 civarında olan Nükleer enerji nötr kaynak olarak nitelendirilmektedir. Enerji, türü ne olursa olsun, üretim ve kullanımı sırasında çevreye toz ve gaz şeklinde kirleticiler salınır ve bunlar ölümcül sonuçlar da doğurur. Ülkemiz enerji kullanımında kirletici fosil yakıtların toplamı \%90 mertebesinde olup, dişa bağımlılığımız yüksek düzeydedir. Yurdumuzda bilinç oluşmuş, fosil kirleticilerden kaçış başlamıştır. 2020 yılı itibariyle kömür santrallarının bir kısmı kapatılmış, bu yolla kirletici toz ve gaz çıkışları azaltılmış ve büyük şehirlerimiz hava kirliliği düşürülmüştür.

Tozların buz kitlesinde yer eden miktarları bilim adamları tarafından ölçülebilmekte ve tarihe not düşülebilmektedir. Adeta buz içindeki tozun bulunduğu derinlik ile tarihi derinlik ilişkilendirilebilmektedir. Örneğin, Arktik Rusya Buzulunda ve Grönland Buzulunda ölçümler yapılmış ve metrekare alandaki toz ve/veya moleküler yapı ağırlığı bulunmuştur. Kurşun için, 1940 yılından sonraki dönemlerde tarih boyunca hiç görülmemiş yükseklilerde kurşun izleri tespit edilmiştir. 1970'e kadar, atmosferde görülen aşırı yüksek kurşun birikimi daha çok kömür yakma, kurşunlu benzin ve kurşunlu duvar boyalarıyla ilişkilendirilmiştir. 1970 sonrası otomobillerde kurşunlu benzinin yasaklanması, Sovyetler Birliğinin dağılması ve ekonomik çöküşü, çevre bilinci ve ekonomilerin kurşunsuzlaştırılması nedeniyle emisyonlarda kayda değer miktarlarda düşüş yaşanmış ve bu buz içi iz miktarla-

1 W. Pal - T.S. Uyar, 2000-2020 Yıllarında Güneşin Zaferi, İstanbul, EUROSOLAR Türkiye İktisadi İşletmesi Yayını, 2019, s. 75. 
rıyla ilişkilendirilmiştir. Bu gerçeklik, yaşanmışlıklarla örtüşmekte ve günümüz KOVID-19 nedenli etkilerle birlikte geçmiş yıllar da irdelenebilmektedir. ${ }^{2}$

1940 sonrası insan çağıdır, o tarihten günümüze kadar malzeme ve enerji tüketimi çok artmış, doğal süreçler ve dengeler büyük ölçüde insanlar tarafından değiştirilmiştir. ${ }^{2,3}$ Yüksek orandaki salınımlarda, çevre kirliliklerinde ve yansımasını gördügüüüz küresel iklim değişikliklerinde ana aktör insandır. Bu makalede, endüstriyel tozlar ile çöl tozlarının insan ve çevre sağlığına etkisi verilecektir. Ayrıca koronavirüs salgını-hava kirliliği ilişkili gerçeklikler de tartışılacaktır.

\section{1. Şehirlerde Hava Kirliliği}

Endüstri kuruluşlarından yayılan toz ve dumanlar (cıva, kurşun, kadmiyum gibi ağır metal bileşenleri, dioksin, furan gibi organik kimyasallar ve uçucu baca külleri), endüstriyel ürüne dönük muhtelif küller, ve her türlü araç egzoz çıtılları şehir atmosferinde yı ğılma gösterebilir. ${ }^{3,4,5,6} \mathrm{Ev}$ eksenli ve çevresel atıklar, yetersiz yanma sonucu dumanda kalan veya taşınımdan sonra yeryüzüne inen siyah karbon partikülleri, ozon ve metan gibi birçok uçucular şehirlerde konforsuzluk doğurabilir. Jeneratör dizeli, fuel oil ve kömürün yanmasından muhtelif gazlar ve partiküller çıkar. Bunların arasında çok sayıda ve çeşitte mikro-nanoparçacıklar vardır. Havanın kirleticilerden, özellikle PM $10(10 \mu \mathrm{m}$ altı) ve PM 2.5 (2.5 $\mu \mathrm{m}$ altı) partikül maddelerden, temizlenmesi her yıl milyonlarca canı ölümden kurtaracaktır. ${ }^{3}$ İklim değişikliğine etki eden olarak düşünülen karbondioksit, su buharı ve metan gazı farklı kategorik bakışla ele alınmalıdır. Soluduğumuz şehir atmosferi kirleticileri ve sağlık etkileri iki ana bileşen, ad olarak partikül madde ve azotoksit, için aşağıda verilmiştir.

a) Partikül Maddeler (PM10, PM2.5), Ana Kaynağı: Sanayi, yakıt yanmas1, tarım ve ikincil kimyasal reaksiyonlar. Sağlık Etkisi: Kanser, kalp problemleri, solunum yolu hastalıkları, bebek ölüm oranlarında artış.

b) Azotoksitler, Ana Kaynağı: Taşıt emisyonları, yüksek sıcaklıkta yakma prosesleri. Sağlık Etkisi: Göz ve solunum yolu hastalıkları, asit yağmurları.

Karbon monoksit ve siyah karbon ikincil kirleticilerdir. Kükürt dioksit, fosil yakıt yanması (ve yangınlar) sonucu dumanda kalır ve asit yağmurlarına sebebiyet verir. Ozon, trafikten kaynaklanan azot oksitler ve uçucu organik bileşiklerin

2 M. Fishetti, "Heavy Metal History”, Scientific American, October 2020, p. 76

3 F. Yılmaz, "Çöl tozları, iklim ve sağlık", Dünya Gazetesi, 07 Mayıs 2011.

4 "Graphic detail air pollution", The Economist, November 9th 2019, p. 77.

5 "The World in Numbers", The Economist The World in 2021, December 2020, p. 99.

6 "Breath uneasy", The Economist, February 7th 2015, p. 47-50. 
(VOC) güneş 1şı̆̆ıyla değişimi sonucu oluşur ve solunum sistemi problemleri, göz ve burunda kaşıntı, astım, vücut direncinde azalmaya sebebiyet verir.

EPA (Çevre Koruma Ajansı) ${ }^{7}$, ülkelerin ekonomik büyümesi ile hava kirliliği eksenli ölümler arasında enteresan bir ilişki vermiştir. Başlangıçta az gelişmiş ekonomiler, çevre ve hava kirliliği yüklü ekonomik büyüme gösterirler. Bu ülkeler, ekonomileri büyürken çevreyi çok kirletirler ve hava kirliliği eksenli ölüm oranları da yüksektir. Ülkeler yeteri zenginliğe eriştiklerinde, kirlilik ve bundan dolayı ölümleri azaltıcı tedbirleri almaya başlarlar. Fert başına düşen gayrisafi milli hasılası (GSMH) satınalma paritesine göre 5.000-15.000 ABD Dolar mertebesinde olan ülkeler (Hindistan gibi) ilk evre içindedirler. Zenginleşen ve yetkin duruma gelen ülkeler (Çin, Türkiye, Singapur ve Japonya gibi) ikinci evreye geçmişlerdir. Bu evrede ülkeler, çevre yatırımlarını arttırarak, hava kirliliği eksenli ölümleri düşürürler. Türkiye'nin 1990'larda 100.000 kişide 60-70 olan hava kirliliği ölümleri, 2010'lu yıllarda 40-50'ye düşmüştür (Türkiye'nin 2020 y1lı satınalma paritesine göre fert başına düşen GSMH's1 30.000 ABD Dolarıdır). Bizden çok zengin olan Singapur'da düşüş daha çarpıcıdır, 1990 yılında 100.000 kişide 43 civarında olan hava kirliliği ölümleri 2017'de 20'ye inmiştir (Singapur'un 2020 yılı satınalma paritesine göre fert başına düşen GSMH's1 102.000 ABD Dolarıdır). ${ }^{8}$

Hindistanda kirlilik artışı ve hava kirliliği eksenli ölümler yükseliştedir (100.000 kişide 70), Çin'de ise aşağ1 yönelim başlamıştır (100.000 kişide 46). Her iki ülke için verilen 2020 GSMH PP sırasıyla 7.000 ve 19.000 dolardır ve yukarıda verilen belirleme işlerliktedir. Dünyanın en toksik 30 büyük şehrinden 22 'si Kuzey Hindistan'dadır. Bir akademik çalışmada KOVID öncesi dönemde, bu şehirlerde yaşayan 9,7 milyon kişinin 670.000'inin kirli havadan öldüğü -hava temiz olsaydı ölmeyeceği- bilgisi verilmiştir. ${ }^{9}$ Tedbir olarak Hindistan Yönetimi araç ilişkili emisyon problemini önemseyerek, trafiğe çıkışı tek/çift plaka sıralamasına bağlamıştır. Hindistan hava kirliliğinde araç payı \%25 olduğundan bu kararın fazla bir yararı ortaya çıkmamıştır. Yasaklama gerektiren unsurlar; anız (tarla atıkları) yakma, çiftçilere pirinç ekme desteğinin kaldırılması yoluyla yüksek hasadı önleme, geleneksel 1şık festivalinin yapılmaması ve endüstride/evde kömür yakmadan vazgeçmedir. Örneğin, Hindistan Gujarat’taki 300 tekstil fabrikasında buhar üretmek için hâlâ kömür yakılmaktadır. EPA, Hindistan gibi gelişmekte olan ülkelerde kömür ve enerji santrallarındaki emisyonun hava kirliliğin-

7 "Graphic detail ....", a.g.m.

8 "The World in....", a.g.m.

9 "Breath uneasy", The Economist, February 7th 2015, p. 47-50. 
de ana unsur olduğunu belirtmiştir. 660 milyon Hintli toksik hava solumaktadır. DSÖ’ye göre dünya genelinde 1622 şehirde hava kirliliği dikkat çekmektedir. Her ülkenin hatta şehrin kendi gerçekliği vardır. ${ }^{10}$

Hindistan'da araba sahipliğinde hanelerin \%5'i gibi düşük oran vardır, ulaşım bisiklet ve toplu ulaşım araçlarıyla sağlanır. 22 büyük şehrin 13'ü kirli hava altında olan Hindistan'da, örneğin Delhi şehrinde PM2,5 sınırı 15 kat aşılmıştır. Çin de Hindistanla yarışır gibidir. 74 büyük şehrin ancak 8'i sınır değerin altında kalabilmiştir. Günlük PM2,5 seviyesi olarak 35 mikrogram / metreküp $\left(35 \mu \mathrm{g} / \mathrm{m}^{3}\right)$ hava güvenlik sınırıdır. Çin büyük şehirlerinin ortalaması ise 93 'tür. Pekinde zaman zaman 500 mikrogram / metreküp değeri aşılmaktadır. ${ }^{11}$ Pekin'de ömrünü geçiren bir kişi muhtemelen 5 yıl daha az yaşayacaktır. Çin, dünyanın en kirli havasına sahip olup, en kirli havaya sahip 20 büyük şehirden 16'sının ev sahibidir. Elektrik enerjisinin \% 75' inin kömürlü termik santrallardan sağlanması ana nedenlerden biridir ( $\mathrm{Bu}, \mathrm{ABD}$ 'de \%50'dir ve düşüş eğilimindedir). Çin'de

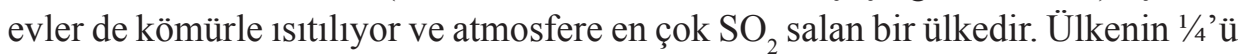
asit yağmuru alır. Dünya Sağlık Örgütü (DSÖ)'ye göre Çin'in 300 şehrinin 2/3'ü hava kalitesi yönüyle eşik değerin üstündedir. ${ }^{12}$

PM10 için Avrupa Birliği tarafından belirlenen $50 \mu \mathrm{g} / \mathrm{m}^{3}$ limit değeri günlük 24 saatin ortalaması olup yılda 7 gün limit aşımı kabul edilmiştir. Ayrıca PM10 y1llık ortalaması ise $20 \mu \mathrm{g} / \mathrm{m}^{3}$ olarak kabul görmüştür. Görüldüğü gibi Avrupa ülkesinde PM10 limitleri oldukça düşüktür ve İstanbul'da bu değerler, anlık ölçümlerin yapıldığ 10 merkezde sık sık aşılmaktadır.

\section{KOVID-19 Etkisi}

Koronavirüs Salgını nedeniyle, 2020 Mart başından itibaren Dünyanın birçok şehri kapandı ve hava kirliliği hızla düştü, Nisan ve Mayıs aylarında dip yaptı sonra gevşemeyi takiben Temmuz'dan itibaren mavi gökyüzü tekrar griye döndü. Aşılama ile beraber rehavete kapılan gelişmiş ekonomilerde hava kirliliği, solunum sağlığı açısından rahatsızlık yaratan COVID-19 öncesi seviyelere yaklaşmıştır. Ülke ve şehir özelinde, kapanma ve açılma günümüze (Mayıs 2021) kadar periyodik tekrarlanmalarla sürmüştür. İnsanlık, KOVID nedenli ölümler ve kapanma ile kapanma sonrası açılma etkili hava kirlilik eksenli ölümler arasında adeta gel-gitler yaşamıştır.

\footnotetext{
10 "Graphic detail....", a.g.m.

11 "Breath uneasy", a.g.m.

12 "A great Wall....", a.g.m.
} 
Virüs, ülkelerde on binlerce ve yüz binlerce insanı öldürdü ve dünyanın dört bir yanındaki ekonomileri altüst etti. Ülkelerin gelirleri düştükçe hava kirliliği de düşüyor! 2020 ilkbaharında, Hindistan'ın kuzeyindeki Jalandhar sakinleri, 160 km (100 mil) uzaklıktaki karla kaplı Himalaya dağlarını ilk defa gördüler. Onlarca yıldır görmedikleri bu güzel manzara, havada daha önce çok bulunan kirletici miktarının düşmesi sayesinde olmuştur. En yaygın kirletici azot dioksittir $\left(\mathrm{NO}_{2}\right)$. Fazla azot hava, toprak ve yaşayan organizma arasında dolaşımdadır. Örnek olarak, suni gübrede azot ve azot oranı artması ile artan tarımsal gıda maddesi üretimi ilişkisi verilebilir. DSÖ, her metreküp havada 40 mikrogramın $(\mu \mathrm{g})$ üzerindeki $\mathrm{NO}_{2}$ seviyelerinin insanlar için zararlı olduğunu belirlemiştir. Dünyanın en kirli büyük şehirlerinden biri olan Delhi'de $\mathrm{NO}_{2}, 2020$ Mart'ında $46 \mu \mathrm{g} / \mathrm{m}^{3}$ ten, Nisan'ın başlarında kapanmayı takiben $17 \mu \mathrm{g} / \mathrm{m}^{3}$ 'e kadar aniden düşmüştür. Benzer şekilde, Londra' daki $\mathrm{NO}_{2}$ seviyeleri Mart ayı içinde ölçülen $36 \mu \mathrm{g} / \mathrm{m}^{3}$ 'ten iki hafta sonra $24 \mu \mathrm{g} / \mathrm{m}^{3}$ 'e düşmüştür. Hava kirliliği tek başına insan faaliyetlerine bağlı değildir, rüzgar hızı, yağış ve nem gibi hava koşulları da etkilidir. Bir düşünce kuruluşu olan Enerji ve Temiz Hava Araştırma Merkezi (CREA), KOVID-19'un dünyadaki 12 büyük şehirde hava kirliliği seviyeleri üzerindeki etkisini ölçmek için bu faktörleri dikkate alan bir model üretti. $\mathrm{NO}_{2}$ seviyelerinin, hükümetlerin evde kalma emri vermesinden on gün sonra 2017-2019'un aynı dönemine kıyasla yaklaşık \%27 düştüğü bulunmuştur. DSÖ tarafından, dünya nüfusunun yaklaşık \%90'ının hava kalitesinin kötü olduğu yerlerde yaşadığı tahmin ediliyor. 2016 yılında 290.000 çocuk dahil 4.2 milyon kişinin solunum yolu enfeksiyonları ve akciğer kanseri gibi hava kirliliğiyle ilgili hastalıklardan erken öldüğü düşünülüyor. Milyonlarca kişi kronik sağlık sorunundan muzdarip. CREA tarafindan, KOVID-19 salgını başladığından beri artan hava kalitesi sayesinde büyük şehirlerde yaklaşı 15.000 kişinin hayatının kurtulduğu belirtilmiştir. Delhi'de hava kirliliği nedeniyle tehdit altında olan yaklaşık 4.600 kişi, KOVID-19'un getirdiği temiz hava sayesinde ölümden kurtulmuştur. ${ }^{13}$

Kuzey yarımkürede insanlar hareketlendikçe ve ekonomiler iyileştikçe, hava kirliliği salgın öncesi seviyelere yaklaşmaktadır. İnsanlar toplu taşıma araçlarını kullanmaktan çekiniyorlar, arabalarını kendileri kullanarak işe gitmek istiyorlar ve bu yolla KOVID-19'dan kaçtıklarını düşünüyorlar. Salgın sonrası canlanan iş yaşamı ve artan servis hizmetleriyle ilişkili olarak şehirlerde trafik sorunu daha da artacak, kitlenmeler baş edilemez olacaktır. Bu durum, kirliliğin büyük şehirlerde KOVID-19 öncesi seviyeleri aşacağını göstermektedir. Kirlilikteki bu artış, özellikle KOVID-19'a karşı savunmasız olan astım hastaları için tekraren ölümcül etki doğurabilecektir. 


\section{Araç Egzoz Çıktıları}

Günümüzde büyük şehirlerde KOVID-19 Salgının da etkisiyle, kapanma olduğu halde trafik günün hemen her saatinde yoğundur. Özel araçla işe gitmek bulaş korkusu nedeniyle tercih edilmeye başlanmıştır.

Bugün salgından kaçan insanoğlu, gelecek günlerde kirli hava mı soluyacaktır? Radikal tedbirlerin alınması ve ulaşımda dönüşümün sağlanması şarttır. Bu gelişmeler paydaşları yeni arayışlara yönlendirmiştir. Dönüşüm iki ayaklıdır:

1. Daha az kirleten, hatta sürüş sırasında hiç kirletmeyen çevre dostu ulaşım araçları edinme öncelenmelidir. Aracın kullandığı yakıt özelliği, elektrikli ise elektriğin kaynağı bile gündem yapılmalıdır. Bu nedenle doğru bir karar gereği olarak ülkemizde elektrikli araç ve onun en önemli öğesi olan batarya üretimi faaliyeti hızlandırılmıştır.

2. Özellikle büyük şehirlerimizde yer yüzeyi artan ihtiyaçlarımızı, başta ulaşım ve iletim olmak üzere karşılayamamakta, yüzeye daha yakın derinlikler gündeme gelmektedir. İnsan ve eşyanın tünellerle taşınması, kitle ulaşım araçlarının teşviki ve evde çalışmanın özendirilmesi ikinci çözüm önerimizdir.

1913 'te Henry Ford'un/ABD seri üretim aracı (T Model) ile maliyet çok düştü. 1980'lerde Taiichi Ohno'nun/Japonya Toyota üretim sistemine uygulad1$\breve{g} 1$ anında üretim-yalın üretim metodu ve parçaların anlık temini sistemi fabrika verimliliği için küresel bir kıyaslamaya yol açtı. ABD’li girişimci Elon Musk, 2000'li yılların başında birçok yeniliklerle elektrikli arabaları (Tesla) üretti, şimdi kitlelere yaymaya çalışıyor. Tesla yeni iş modelinin en dikkat çekici olanı ise çevre dostu olmaktır. Musk'in büyük hedefi, müşterilerine yeşil yaşam sunmaktır. Elektrikli otomobil olarak da anılan Tesla'nın araçları oldukça hafif olup birçok yenilikçi sistemler ve malzemeler içermektedir. Araçlar, nadir toprak metalleri, petrokimya ürünü plastikler, silis pencere camları, iç ve dış tasarımda karbon fiberler, elektronik parçalarda bakır tel, gövde ve kasisler boksit mineralinden elde edilmiş hafif alüminyum alaşımı, gövde altı yüksek mukavemetli titanyum alaşımı ve yüksek mukavemetli borlu çelikten meydana gelmiştir. Kurşun-asit, nikel-kadmiyum, nikel-kobalt, lityum-iyon ve alüminyum-iyon gibi türleriyle bataryalar (aküler) elektrikli araçların en önemli öğeleridir. Uzun şarj süresi, tam doluluğun sağlayacağı sürüş mesafesi (menzil), batarya dolum istasyon zincirleri mevcudiyeti, dolumda kullanılan bakır kabloların çalınma riski ve ömürlerini dolduran bataryaların çevresel etkileri bugün en çok tartışılan konulardır. Yenilenebilir enerji kaynaklarından gelen elektriği kullanan ulaşım sistemleri ve araçları ana kulvarı oluşturmaya başlamıştır. ${ }^{14}$

14 F. Yılmaz, "Elektrikli otomobil, küresel rekabet ve gelişmeler”, Dünya Gazetesi, 24 Aralık 2017. 
Çağımızda, enerji tüketimini ve hava kirliliğini azaltan yakıt verimli araç üretimi ana hedeftir. Ağırlık azaltma yakıt ekonomisine katlanmalı şekilde olumlu etki yapar. Aynı performans, daha küçük motorla, daha küçük aktarma organıyla, daha küçük yakıt tankıyla, daha küçük bataryalarla (elektrikli araçlar) sağlanacağından \%10 ağırlık düşürme eklemeli olarak \%8-10 yakıt ekonomisi ve tasarruf sağlar. Bu ve benzeri başka tedbirler, daha az kirli hava ve daha az kirlilik eksenli ölüme yol açacaktır.

Gelişmiş ekonomilerde, ABD gibi, hava kirliliğinin ana nedenlerinden biri ulaşım sektör çıktılarıdır. Son yıllarda çok kirletici olan SUV (Sports Utiliy Vehicle-Spor Hizmet Aracı) kullanımı rahatsızlık verici ölçüde artmıştır. SUV büyük şehir kenar mahallelerine dönük bir araç olmasına rağmen şehir merkezlerinde de yoğun şekilde kullanılır. Yeni bin yılın insanları SUV'u çok benimsediler, ona aile arabası, eşya taşıma arabası, dağ arabası gibi çok fonksiyonluluk verdiler. SUV'lar, şehir yaşamı, hava kalitesi ve yaya güvenliğini olumsuz etkiler. IEA'na göre, geçen 10 yilda $\mathrm{CO}_{2}$ emisyonunda en büyük paydaşlardan biri SUV'dur. SUV demek 100 kg'lık bir kişiyi 3000 kg'la taşımak demektir. SUV'lar yalnız kirletici değil, yayalar ve iki tekerlekli araçlar için de korkutucudur. Dünyada, 2019'da satılan toplam araçların \%40'1 SUV'dır.

Ulaşım sektörü tamamen dekarbonize edilmelidir. Yolda yürüme, bisiklet veya e-kaykay kullanma, kitle ulaşım aracı kullanma kültürü geri gelmelidir. Emisyon salma oranı yüksek araçlar (SUV gibi) sigara karşıtı bilgilendirmeler gibi reklamlanmalıdır. ${ }^{15}$ Arac türü ne olursa olsun, Temiz Hava Yönergesine uyumda Japonya ve Güney Kore hariç Asya ülkeleri gereken önemi göstermemektedir. Örneğin, Çin'in en gelişmiş şehri Shanghai'deki 1 milyon aracın \%70'i Avrupa Emisyon Standardına uyamamaktadır. ${ }^{16}$

Otoyol eksenli olarak şehirlerde soluduğumuz havayı kirleten çıktılar ve etkileri aşağıda verilen tedbirlerle azaltılabilir:

a) Trafik akışının iyileştirilmesi

b) Durma sayısının ve keskin dönüşlerin azaltılması

c) Yol eğimini azaltılması

d) Hız limitine uyumun sağlanması

e) Katarlı araç sınırlaması

f) Yeni araç standartlarını yürürlüğe koyma

15 “Axles of evil", The Guardian Weekly, 11 September 2020, p. 28-29.

16 "A great Wall....", a.g.m. 
g) Mevcut araçların iyileştirilmesi

h) Verimli yanmayı sağlayan yakıt ilaveleri kullanma

1) Araç inceleme ve bakım programlarını geliştirme

i) Alternatif araç yakıtı önerme

j) Araç hurdaya ayırma/değiştirme programı önerme

k) Paralı geçiş uygulaması

1) Rampa ölçme uygulaması

m) Etkili yol kenarı yardımı sağlama ve

n) Ağır vasıtalara (kamyonlara) ayrı hat vermedir. ${ }^{17}$

Araç yapı malzemeleri üretimi ve montajı için kullanılan enerji ve atık çıktıları ile aracın kullanım boyu enerji tüketimi ve emisyon çıkışı dikkate alınmalıdır. Örneğin elektrikli aracın ne boyutta çevre dostu olduğu, kendi ve bataryaları için hammadde çıkarma, petrol eldesi ve şarj için kullanılan elektrik kaynaklı atık salınımları dikkate alınmalıdır. En önemlisi ise araç ömrü boyunca sürüş sırasındaki salınan emisyondur. ABD için hesaplamalar, aracın bir yıl içinde ağırlı̆̆ının 2 katı emisyon saldığını vermiştir. Aracın, 1 yılda 15.000 km yol aldığını ve 100 $\mathrm{km}$ de 10 litre yakıt harcadığını düşünelim. Yılda $1.500 \mathrm{~kg}$ benzin (Benzin \%85 karbon) harcanır ve bunun 3 katı karbondioksit gazı partiküllerle birlikte salınır. 15-20 yıllık kullanım süresi demek araç enerji tüketiminin ve atık salınımının \%94'ünün kullanım sırasında gerçekleşmesi demektir. Hammadde üretim, parça imalat ve montaj payları toplamı \%5'tir. \%1'lik son pay ömrü dolduktan sonra aracın parçalanması, malzeme gruplarının ayıklanması ve geri dönüşüme gönderilmesi kalemleri oluşturur. Muhtelif evrelerin enerji payları, gaz ve toz salınım payları ile aynı mütala edilebilir.

Bataryalı elektrikli araba için kömür santralı elektriği kullanılacaksa, içten yanmalı (benzinli) günümüz araç sistemine göre 3 kat fazla ölüme neden olan hava kirliliği beklenmelidir (melez araçta fazla değişmez). İnce PM2,5 tozlar ve yer ozonu ABD'de yılda 100.000 hava kirliliği eksenli ölüme sebebiyet vermektedir. ${ }^{18,19}$

17 F. Y1lmaz, "Otoyollar, hava kirliliği ve 10 numara yakıt”, Dünya Gazetesi, 16 Şubat 2013.

18 C. W. Tessum - J. D. Hill - J. D. Marshall, "Life cycle air quality impacts of conventional and alternative light-duty transportation in the United States", PNAS, 111(52), December 30, 2014, p. 18490-18495.

19 “Cleaner than what?", The Economist, December 20th, 2014, p. 16. 
Elektrikli arabaların kullandıkları elektrik kaynağına bağlı olarak oluşan hava kirliliğinin bir y1l boyu görece ölümcül etkileri, diğer alternatiflerle birlikte ABD için Şekil 1'de verilmiştir:

a) Rüzgâr, güneş ve hidro enerji kaynaklı elektrik ile beslenen bataryalı araç:231 ölüm/yı1.

b) Benzinli (petrol) araç:878 ölüm/yıl.

c) Doğal gaz kaynaklı elektrik ile beslenen bataryalı araç:439 ölüm/yıl.

d) Kömür Santralı kaynaklı elektrik ile beslenen bataryalı araç:3200 ölüm/yıl.

Biyoyakıtlı (mısır) araç benzinli araçtan daha problemlidir. Dizel yakıtlı araç benzinliden daha az problemlidir. $\mathrm{Bu}$ aracı avantajlı kılan, filtre ile partikül tutma kapasitesinin iyi olması ve daha iyi yakıt ekonomisidir. Sonuç olarak elektrikli arabalar eğer elektrik kaynağı da temiz ise, içten yanmalı klasik benzinli araçlara tercih edilmelidir. Elektrikli arabanın ne kadar yeşil olduğu, biraz da ülkesine bağlıdır. Örneğin Fransa'da elektrikli araç süren kişi, Çin'deki elektrikli araç sürene göre daha çevre duyarlıdır. Sebep açıktır. Yaklaşık aynı oranlarda olmak üzere $(\% 75$ 'ler), Fransızlar elektrikli araca hava kirliliği yapmayan yoğun nükleer ağırlıklı elektrik enerjisini şarj ederken, Çinli çok kirletici olan kömür yakıt santralı elektriğini kullanır. ${ }^{12,13}$ 


\section{Partikül Madde}
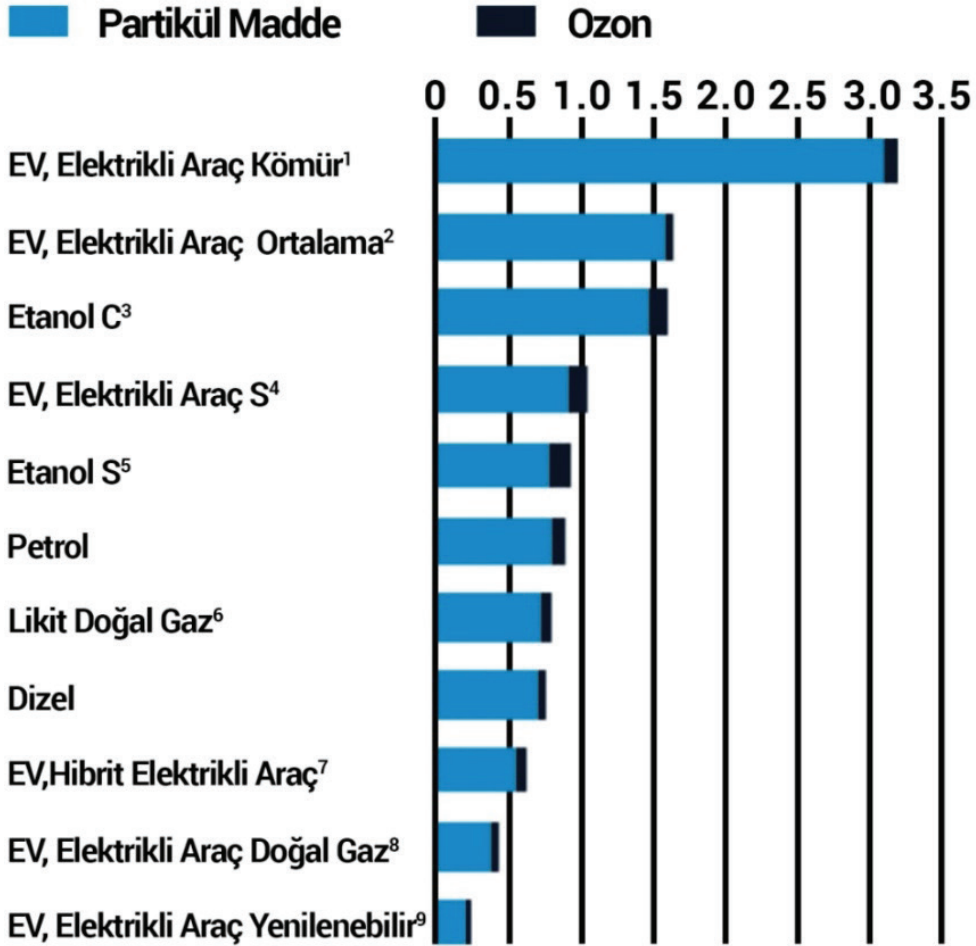

*Bu grafik 2020 yılında Amerika'daki araçların kat ettikleri toplam mil uzunluklarının \%10'unu kapsamaktadır 'EV, Elektrikli araç kömürden şarj edilen ${ }^{2} \mathrm{EV}$, Elektrikli araç $\mathrm{ABD}$ tüm elektrik üretici karışımından şarj edilen ${ }^{3} \mathrm{Etanol}$ biyogaz yakıtlı (darıdan-mısır) ${ }^{4} \mathrm{EV}$, Bitki yaprak ve saplarından (mısır) elde edilen enerji ile beslenmiş olan ${ }^{5}$ Bitki yaprak ve saplarından elde edilen Selülozik Etanol yakıtı ${ }^{6}$ Likit (sıkıştınımış) doğal gaz ${ }^{7} \mathrm{EV}$, petrol yakıt destekli dış eklentisiz elektrikli araç ${ }^{8} \mathrm{EV}$, doğal gaz elektriği ile çalışan araç ${ }^{9} \mathrm{EV}$, rüzgar, güneş veya hidro kaynaklı elektrikle çalışan araç. Kaynak: Tessum, Hill and Marshall, PNAS

Şekil 1. ABD'de hafif araçlarda, kullanılan yakıt türüne göre oluşan hava kirliliği eksenli yıllık ölümler* $(\mathrm{X} 000){ }^{20,21}$

\section{3. Çöl Tozları}

Son yıllarda umulmadık coğrafyalarda, sık aralıklarla ani bastıran kum firtınası nedeniyle onlarca ölüm, onlarca araç hasarı ve esip savuran hareketli toz bulutu oluşumları görülmektedir. Bunlar ve uzun süreli sis benzeri gelir geçer

21 "Cleaner than....", a.g.m. 
hava hadiseleri, hiç çölün olmadığı Kuzey Avrupa'da ve ülkemizde artık sıradanlaşmıştır. Geçtiğimiz yıllarda yapılan incelemeler ${ }^{22}$, toz ve kumların ülkemize Afrika Sahra Çölü, Suriye Çölü, Arabistan Çölleri ve İran Çöllerinden geldiğini vermiştir. Çevreyi adeta kırmızı, kahverengi ve sarıya boyayan bu tozlar, yalnızca çatıları, damları, arabaları ve yolları kaplamıyor, hava sıcaklığını da değiştiriyor, genellikle düşürüyor. Benzer şekilde, Çin'de Gobi Çölü’nden gelen toz ve kumlar Pekin'i ve birç̧ok şehri sık sık sarıya boyamaktadır. Farklı yöre çölleri beklendiği gibi farklı bileşime sahiptir, onların taşınımdaki tozu ve dumanı da farkl1 renge sahiptir.

Çok küçük boyutlardaki partikül maddeler, rüzgarlar tarafından yeryüzünden havalandırılarak atmosfer içinde çok uzak mesafelere kadar taşınmaktadır. Çöl tozlarının rüzgarla taşınımı, doğal ve beşeri ortamı çok önemli mertebede etkiler. Birincil etkiler iklim, bitki ve toprak örtüsü, su kaynakları ve hava kalitesinde görülür. Toz miktarının yüksek olduğu zamanlarda akciğer ve solunum yolları hastalar1, kalp-damar hastaları ve migren hastaları olumsuz olarak etkilenmekte ve hastalıkları tetiklenmektedir. Çöl tozlarının içerisinde bulunan mikroorganizmalar, bakteriler, sporlar ve mantarlar muhtelif hastalıklara (menenjit gibi) ve salgınlara yol açmaktadır. Tozların zararları tane büyüklüğüne bağlı olup PM2.5 (2.5 mikrometre altı) tozlar akciğerde tutulur ve kalıcı hasar oluşturur. Toz miktarı yüksek olduğu zamanlarda kara, hava, deniz ve demir yolları ulaşımı ve ekonomiler de etkilenmektedir. ${ }^{23}$

Sanayi öncesi dönemde yeryüzü topraklarının $\% 5$ 'ini bulan tarım arazi oranı, bugün artan nüfus ve savurganlık nedeniyle \%45- 50'yi bulmuştur. Örneğin Çin'de ormansızlaşma ve tarım arazisi açmanın sonucu olarak sarı çöl tozu (onlarca milyon tonluk kükürt dioksitli toz ve duman) taşınımı çok artmış ve geniş coğrafyaya yayılmıştır. Bu gerçeklik ve doğan zarar ülke milli gelirinin \%10'una mal olmaktadır. Bunlar kısaca, hasat kaybı, asit yağmurları etkisi, sağlık harcamaları, hastalık dolayısıyla çalışamama-işgücü kaybı, sel baskını ilişkili felaket giderleri, doğal kaynakların fakirleşme giderleridir. Çin'de onlarca yıllık ihmal ülkeyi sınır noktasına getirmiş, doğal kaynaklar nüfusu taşıyamaz olmuştur. Mao, "İnsanlar doğayı keşfetmeli ve onun boyunduruğundan kurtulmalıdır" demiştir. ${ }^{24}$ Çin, liderinin bu mesajını yerine getirmiş, fakat aşırıya kaçmış, üretimi adeta kutsamış ve büyümeyi uzun süre \%9 GSMH artış1 şeklinde sürdürmüştür. Bugün

22 M. T. Şengün - K. Kırşan, "Çöl tozlarının Türkiye'de doğal ve beşeri ortam üzerine etkisi”, Firat Üniversitesi Sosyal Bilimler Dergisi, cilt 22, sayı 2, Elazı̆̆, 2012, s. 1-15.

23 M. T. Şengün, a.g.m.

24 “A great Wall....", a.g.m. 
atık ve atmosferik çıktıları ile sadece Çin değil, bütün dünya bedel ödemektedir. Batı ülkelerinde deli ve aceleci barbarlar hırs ve iştah dolu egemen güçler, maalesef devletlerinin desteğini de arkalarına alarak maksimum güç elde etme ve yağmacılığı tarz yapmışlardır. İnsanlar, doğayı keşfetmek, boyunduruğundan kurtulmak şöyle dursun, doğaya ve canlı yaşama çok müdahale etmişlerdir.

Büyük Sahra ve diğer kuru çölleşmiş bölgeler sürekli atmosfere toz gönderir. Otomatize olmuş fotometrelerle, uydulara ve uçaklara yerleştirilmiş kameralarla toz hareketleri izlenebilmektedir. Taşınımda tozların nereden kaynaklandığ hangi yönlere taşındığ 1 , kuru ve yaş halde nereleri ne şekilde etkilediği bilgisi uydular vasitasıyla takip edilebilmektedir. Tozlar farkl1 incelikte olup genellikle 1 ile 20 mikrometre boyutlarında yığılma vardır. Taşınımdaki görünür tozların üst boyutları 100 mikromereyi aşabilmektedir. ${ }^{25}$ Taşınım sırasında ince partiküller birbirlerine yapışır ve salkımlaşırlar, şartlara bağlı olarak ayrılırlar. İri partiküller ise yere geri düşer, bir kısmı uzaya yayılır. Büyük partiküller düşerken salkımlaşmış partikülleri döver, parçalar ve inceltir. Parçalanma sonucu gökyüzünde farklı partikül boyutlarına sahip devasa bir toz yığını oluşur. Atmosferik toz olarak anılan bu ince partiküllerin boyutları 0.001-1 mikrometre (1 ile $1000 \mathrm{~nm}$ ) arasında değişmektedir (Tablo 1).

Yer kürenin madencilik işlemi yapılabilir kalınlıktaki analizi ortalama olarak aşağıda verilen elementer yüzdelere sahiptir (Element-\%): Oksijen-47, Silisyum-27, Alüminyum-8, Demir-5, Kalsiyum-4, Sodyum-3, Mağnezyum-2 ve diğerleri. Bu listenin son dört elementinin akla getirdiği ilk şey toprağ 1 ve canlıları besleyicilikleridir. İkinci unsur ise demirin renk (kırmızı) vericiliğidir. Çöl tozlarının şaşırtıcı faydaları ve ekosistemi düzenleyicilikleri de vardır. 2008'de Avrupalı Meteorolojistler, toz bulutunun Güneş ışığını geri yansıttığını ve altında su bulutu oluşturduğunu bulmuşlardır. Yoğun toz bulutu, ileri aşamada Güneş 1sısının dünyaya ulaşmasını önler ve yeryüzünü soğutur. Küresel ısınma, çöl alanı artması ve bazı bölgelerde toz üretiminin artması anlamına gelir. Taşınımla atmosferde toplanan ince tozların büyük kısmı yağmurla çamur şeklinde yeryüzüne iner. Kimine göre bu çevre kirliliğidir, kimine göre ise bereket getirir, toprak ve suyu besler. Yağmur bulutlarında düşük $\mathrm{pH}$ ortamı oluşur ve tozlarda bulunan demirde iyonik dönüşüm gerçekleşir. ${ }^{26}$ Tozla birlikte uçuşan bakteriler

25 T. Peker, "Amelyathanelerde standart, yönetmelik ve denetim boşluğu ve MMO yaklaşımı", VIII. Ulusal Tessat Mühendisliği Kongresi, Seminer Bildirisi, Temmuz 2007, p. 769.

26 G. Rubasinghege - S. Elzey - J. Baltrusaitis - P. M. Jayaweera - V. H. Grassian, "Reactions on Atmospheric Dust Particles: Surface Photochemistry and Size-Dependent Nanoscale Redox Chemistry", J. Phys. Chem. Lett., 1, 2010, p. 1729. 
yağmur bulutları ile buluşunca (ıslanınca) aktifleşir ve dönüşümü hızlandırır. Güneş enerjisinin yeterli olduğu mevsimlerde (ülkemiz için Mart-Kasım dönemi), gündüz toz bulutu içerisinde +2 değerli demir miktarı artar, çamur şeklinde yeryüzüne indiğinde insan, hayvan ve bitkiye bereket-sağlık verir. ${ }^{27}$ Anadolu kültüründe Nisan yağmurlarının faydasını anlatan deyişler vardır. Bunlardan biri: «Nisan yağmuru koyunun sırtında et, tarlada ot yapar.» Karaya ulaşamayan tozlar denizde de benzer etkiyi yapar. Okyanuslar demirce fakirdir, kırmızı çöl tozu ise demir zenginidir. Çin'deki Gobi Çölü’nden yükselen demir yüklü tozlar besin değeri fakir olan Pasifik Okyanusu'nu (Kuzey Pasifiği) demirle beslemektedir. $\mathrm{Bu}$ süreç, atmosferdeki karbondioksitin azalmasını sağlamaktadır. Bu besi sayesinde, plankton denen canlı deniz organizmaları büyümekte ve nihayetinde karbondioksit tüketerek deniz dibine batmaktadır. Yağan çamurlu su, plankton (alg) oluşumunu desteklemekte, ayrıca hamsi balığı gibi deniz hayvanlarını da beslemektedir. ${ }^{28,29}$

Küresel 1sınma sonucu oluşan çölleşme, toz kümeleri ve içerikleri ile dengelenmektedir. Afrika tozları Amazonlar'daki bitki büyümesini de etkilemektedir. Amazon ormanları toprağında fosfor düşüktür ve fosfor yüklü tozların yağmurla yeryüzüne inmesi sonucu bu açık kapanmaktadır. Amazonlar'ın derinliklerinde teknoloji ile karşılaşmamış sağlıklı kabileler hayatiyetlerini bu besin dolu yağmurlara borçludur. Bu toz sayesinde, yetişen büyük yapraklı bitkiler karbondioksit emilmesini sağlar, bir şekilde küresel 1sınmayı önler. Amazon bitkilerinin küresel 1sınmayı düşürmelerinin Sahra tozu ile ilişkilendirilmesi herkesi şaşırtmaktadır. Sonuçta, taşınım ve dönüşüme uğrayan demirli ve fosforlu tozlar küresel ısınma nedeni olan atmosferik $\mathrm{CO}_{2}$ 'i azaltmaktadır.

27 İ. Durukan, "Yağmur Sularında İndirgenmiş Demir $(\mathrm{Fe}+2)$ Ölçümü İçin Otomatik Analiz Sisteminin Geliştirilmesi”, (Yayımlanmamış Yüksek Lisans Tezi), Hacettepe Üniversitesi Fen Bilimleri Enstitüsü, Ankara, 2007.

28 F. Y1lmaz, "Çöl....", a.g.m.

29 M. T. Şengün, a.g.m. 


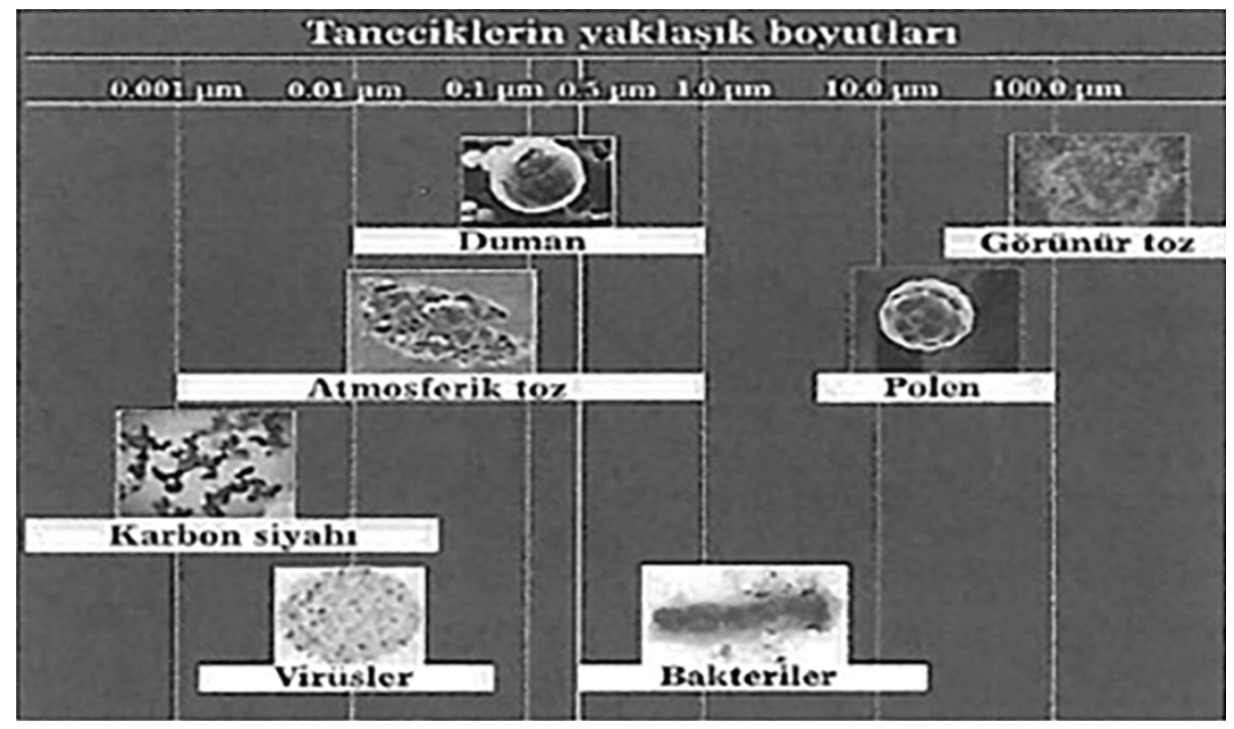

Tablo 1. Toz yığınları ve dumanlarda bulunan taneciklerin mikrometre $(\mu \mathrm{m})$ olarak yaklaşık boyutları (logaritmik ölçü) ${ }^{30}$

\section{Sonuçlar ve Öneriler}

İnsan, dünyamızdaki karmaşık ekosistemin sıradan bir parçası değildir ve çevreye etkisi çok fazladır. Olumsuz ve ekosistemi bozucu etkiler bugün sürdürülemez boyutlara varmıştır. Kararlı adımlar iyileşmeyi verebilecektir. Bu, geçen asrın sonunda ozon deliği tartışmalarında görülmüştür. Dünyalılar ozon tabakasını CFC gazları salarak önce incelttiler, sonra ortak kararlılıkla bu asrın başında ozon onarılmış ve sonucu olarak Güney Yarımküre'de cilt kanseri oranları düşmüştür.

Endüstrilerden, konutlardan ve servis sektörlerinden (ulaşım gibi) çıkan her türlü toz ve duman gibi emisyonların düşürülmesi önemsenmelidir. Kaynakları ve sistemleri karbonsuzlaştırma, özellikle araçların toz ve gaz çıktılarının (karbon dioksit gibi) kontrollü şekilde azaltılması hedeflenmelidir. Biz kararlı olursak atmosferik hava kirliliğini azaltabiliriz ve şehirlerimizi daha yaşanılır hale getirebiliriz.

İnsan etkisi ile oluşan yerküre iklimsel (küresel 1sınma gibi) denge kaçıkl1ğ1 doğal süreçlerle (çöl tozları gibi) karşılanmakta ve dengeye yaklaşılmaktadır. Dengelemeye toz etkisi ile atmosferik soğuma ve toz yüklü çamur yağışı ile canlı varlıkları besleme örnek verilebilir. Yerküre adeta kendini doğan duruma göre 
ayarlamaktadır. Olan şeylere ve yaptığımız kötülüğe karşı dünya canlı gibi tepki göstermektedir. Kum firtınaları, depremler, tayfunlar, seller ve yanardağ püskürmeleri gibi örnekler bu tepkilere bizim verdiğimiz adlardır.

İnsanoğlu kendini sorgulamalı ve enerji obur, malzeme obur yaşam tarzı$\mathrm{n}$ 1 değiştirmelidir. Aşırı tüketim ile çevreye aşırı toz ve gaz salımı, canlı-cansız varlıkların doğallıklarını bozmakta, son aşamada insanlar için ölümcül sağlık sorunları doğurmaktadır. 


\section{Kaynakça}

"A great Wall of waste", The Economist, August 21st, 2004.

"Axles of evil", The Guardian Weekly, 11 September 2020.

"Breath uneasy", The Economist, February 7th, 2015.

“Cleaner than what?", The Economist, December 20th, 2014.

Durukan, İ., "Yağmur Sularında İndirgenmiş Demir $(\mathrm{Fe}+2)$ Ölçümü İçin Otomatik Analiz Sisteminin Geliştirilmesi”, (Yayımlanmamış Yüksek Lisans Tezi), Hacettepe Üniversitesi Fen Bilimleri Enstitüsü, 2007.

Fishetti, M., "Heavy Metal History", Scientific American, October 2020.

"Graphic detail air pollution", The Economist, September 5th, 2020.

“Graphic detail air pollution", The Economist, November 9th, 2019.

Pal, W. - Uyar, T. S., 2000-2020 Yıllarında Güneşin Zaferi, İstanbul, EUROSOLAR Türkiye İktisadi İşletmesi Yayını, 2019.

Peker, T., "Amelyathanelerde standart, yönetmelik ve denetim boşluğu ve MMO yaklaşımı”, VIII. Ulusal Tessat Mühendisliği Kongresi, Seminer Bildirisi, Temmuz 2007.

Rubasinghege, G. - Elzey. S. - Baltrusaitis, J. - Jayaweera P. M. - Grassian, V. H., "Reactions on Atmospheric Dust Particles : Surface Photochemistry and Size-Dependent Nanoscale Redox Chemistry", J. Phys. Chem. Lett., 1, 2010.

Şengün, M. T. - Kırşan, K., "Çöl tozlarının Türkiye'de doğal ve beşeri ortam üzerine etkisi”, Fırat Üniversitesi Sosyal Bilimler Dergisi, cilt 22, sayı 2, Elazı̆̆, 2012.

Tessum, C. W. - Hill, J. D. - Marshall, J. D., "Life cycle air quality impacts of conventional and alternative light-duty transportation in the United States", PNAS, 111(52), December 30, 2014.

“The World in Numbers", The Economist The World in 2021, December 2020.

Yılmaz, F., "Çöl tozları, iklim ve sağlık", Dünya Gazetesi, 07 Mayıs 2011.

, "Elektrikli otomobil, küresel rekabet ve gelişmeler", Dünya Gazetesi, 24 Aralık 2017. bat 2013 .

, "Otoyollar, hava kirliliği ve 10 numara yakıt", Dünya Gazetesi, 16 Şu- 


\section{Araştırmacıların Katkı Oranı}

Araştırmanın her aşamasından yazar sorumludur.

\section{Çatışma Beyanı}

Araştırmada herhangi bir çıkar çatışması bulunmamaktadır. 
